\title{
PHOTOLUMINESCENCE OF SMALL-SIZE SEMICONDUCTOR QUANTUM DOTS
}

\author{
N. Žurauskienè \\ Semiconductor Physics Institute, A. Goštauto 11, LT-01108 Vilnius, Lithuania \\ E-mail: zurausk@pfi.lt
}

Received 31 March 2004

\begin{abstract}
The results of photoexcited carrier dynamics and optically detected microwave resonance (ODMR) spectroscopy of smallsize InAs/GaAs quantum dots (QDs) are presented. Very long lifetimes (1-10 ns) of photoexcited carriers were observed in this system by time-resolved photoluminescence measurements. This feature could be exploited to develop high-sensitivity infrared photodetectors based on small-size quantum dots. The ODMR spectra of InAs/GaAs QDs were detected via modulation of the total intensity of the QDs emission induced by $95 \mathrm{GHz}$ microwave excitation, and the exciton fine structure was studied. The microwave-induced signal at magnetic field of $1.6 \mathrm{~T}$ was attributed to magnetic resonance transitions between spin states of holes confined in the dots. The obtained low field (at $0.18 \mathrm{~T}$ ) signal is ascribed to cyclotron resonance of the electron in a two-dimensional wetting layer, corresponding to an effective electron mass of $0.053 m_{0}$.
\end{abstract}

Keywords: nanostructures, semiconductor quantum dots, photoluminescence, optically detected magnetic resonance, infrared detectors

PACS: 78.67.Hc, 78.47.+p, 76.70.Hb

\section{Introduction}

Intense research in the field of self-assembled quantum dots (QDs) has resulted in rapid improvement in their fabrication with controlled structural and electronic properties. In the past decade, several optoelectronic devices, such as lasers and quantum dot infrared photodetectors (QDIP) [1-3], have been developed. QDs provide two main advantages for infrared detectors application: ability to absorb the normally incident infrared photoexcitation, and long, up to nanoseconds, photoexcited carrier lifetimes. Normal incidence photoexcitation is desirable for the fabrication of a two-dimensional focal plane array for passive location imaging applications. The long lifetimes ensure higher responsivity of the detector allowing increased temperature operation. Due to discrete energy levels QDs could be useful for tunable narrow-band detection. These properties of QDs are very promising to design devices capable to determine a unique infrared signature, or "fingerprint," of various objects observed from the space.

Even though a lot of investigations of photoexcited carrier dynamics in self-assembled quantum dots were performed [3-9], carrier relaxation and scattering mechanisms in QDs are still under discussion. Car- rier intersubband relaxation in quantum dots is slower than in quantum wells due to reduced electron-phonon interaction, and emission from excited states in QDs has been observed before the emission from the ground state was saturated (the so-called bottleneck effect) [7]. Moreover, though it has been demonstrated that carrier relaxation could be very fast if Auger-like recombination and impurity-assisted relaxation takes place, it is possible to observe well-resolved excited states in photoluminescence spectra $[8,9]$. The carrier dynamics in small InAs QDs is of great interest in relation with experimental results which have demonstrated that exciton lifetime depends on the transition energy $[4,6]$. The model developed by Sugawara et al. [10] predicted the increase of exciton lifetime with increase of the potential confinement, what means longer exciton lifetimes for smaller QD. To evaluate exciton lifetimes and to avoid influence of carrier redistribution within the whole ensemble of QDs with different sizes, we performed time-resolved (TR) photoluminescence (PL) measurements on extremely small shallowly formed InAs QDs with weakly bound electrons, which are spread out into the two-dimensional wetting layer. The dimensions of the individual dots in the whole ensemble are significantly smaller $(\sim 7 \mathrm{~nm})$ in comparison with the dimensions of the mostly investi- 
gated ensembles of large quantum dots $(\sim 15-20 \mathrm{~nm})$. The increased exciton lifetimes in small InAs quantum dots provided a possibility to perform optically detected magnetic resonance (ODMR) spectroscopy of these QDs. The ODMR technique is a highly sensitive method used to investigate the fine electronic structure of low-dimensional systems $[11,12]$. The first investigations of optically detected cyclotron and magnetic resonance transitions in epitaxially grown InAs/GaAs QDs were reported in [13-15]. In this work, the ODMR results demonstrating strong anisotropy of the spectra are presented and discussed considering the influence of electron confinement on the ODMR spectra.

\section{Samples and experimental set-up}

The investigated InAs/GaAs quantum dots were grown by molecular beam epitaxy of InAs in an amount equivalent to 2.0 monolayers (ML) on a (001) oriented GaAs substrate [16]. The InAs/GaAs QD samples were provided via P.M. Koenraad of the Physics Department of the TU Eindhoven (The Netherlands). The GaAs layer and AlGaAs window were grown to prevent any surface electrical field. The growth process was monitored in situ by means of reflection highenergy electron diffraction (RHEED), which revealed the formation of quantum dots. Due to the relatively high growth temperature $\left(\geq 500^{\circ} \mathrm{C}\right)$ of the GaAs capping layer, the InAs material is expected to be partly diffused into this capping layer. This was confirmed by high-resolution transmission electron microscopy measurements (TEM).

Photoluminescence measurements were carried out at $9.5 \mathrm{~K}$ in a liquid helium cooled optical cryostat illuminating the samples with a few $\mathrm{mW}$ continuous wave $\mathrm{He}-\mathrm{Ne}$ laser operating at $632.8 \mathrm{~nm}$ wavelength.

Carrier dynamics have been studied in the temperature range from 80 up to $230 \mathrm{~K}$ by time-resolved photoluminescence measurements after the excitation with a short laser pulse from a self-mode-locking Ti:sapphire laser (central wavelength $800 \mathrm{~nm}$, pulse duration $100 \mathrm{fs}$, repetition frequency $96 \mathrm{MHz}$ ). A streak camera with an infrared enhanced photocathode combined with a $0.25 \mathrm{~m}$ spectrometer was used for detection. The average excitation intensity was varied by means of neutral density filters in the range from 0.03 up to $10 \mathrm{~mW}$ at a spot diameter of $20 \mu \mathrm{m}$.

The optically detected magnetic resonance (ODMR) spectroscopy of the QDs was carried out at W-band (95 GHz) microwave frequency at $T=4.5 \mathrm{~K}$ using a custom built Fabry-Perot cavity in conjunction with

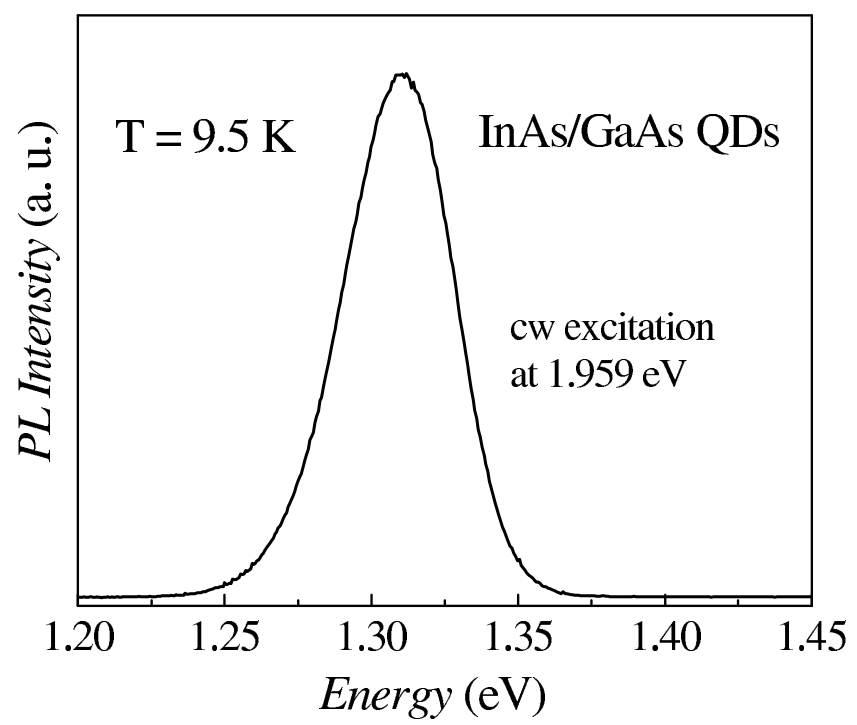

Fig. 1. PL spectrum of shallowly formed InAs QDs under cw excitation with $\mathrm{He}-\mathrm{Ne}$ laser.

a split-coil $6 \mathrm{~T}$ superconducting magnet (Oxford Instruments). Excitation of the sample was performed by using a continuous wave $\mathrm{Kr}^{+}$ion laser operating at $647.1 \mathrm{~nm}$ wavelength with incident power below $60 \mathrm{~mW}$. The emitted light was collected via a quartz light guide and directed through a $900 \mathrm{~nm}$ cut-off filter onto an avalanche Si photodiode. The microwaveinduced changes in the total PL intensity were synchronously detected with the on/off modulation of microwaves at about $3 \mathrm{kHz}$ frequency.

\section{Properties of small self-assembled InAs/GaAs QDs emission band}

The photoluminescence spectrum of InAs/GaAs QDs obtained under cw excitation at low temperatures $(9.5 \mathrm{~K})$ is shown in Fig. 1. It consists of a broad peak centred at $1.31 \mathrm{eV}$ with a full width at half-maximum (FWHM) of $40 \mathrm{meV}$. This inhomogeneous broadening of the line is typical for the whole ensemble of QDs with different size (with fluctuations of about 10\%) and shape what causes the distribution of the transition energies of individual QDs. The relatively high transition energy of $1.31 \mathrm{eV}$ for InAs QDs points to the small effective size of the dots. Indeed, typical transition energies of such type of quantum dots reported in literature are $1.0-1.2 \mathrm{eV}$ for the lowest exciton state. As reported in [16], the edge of the wetting layer (WL) in this system is around $1.35 \mathrm{eV}$. No PL from WL was observed indicating very efficient and rapid capture of photocreated carriers into quantum dots. Figure 2 shows 


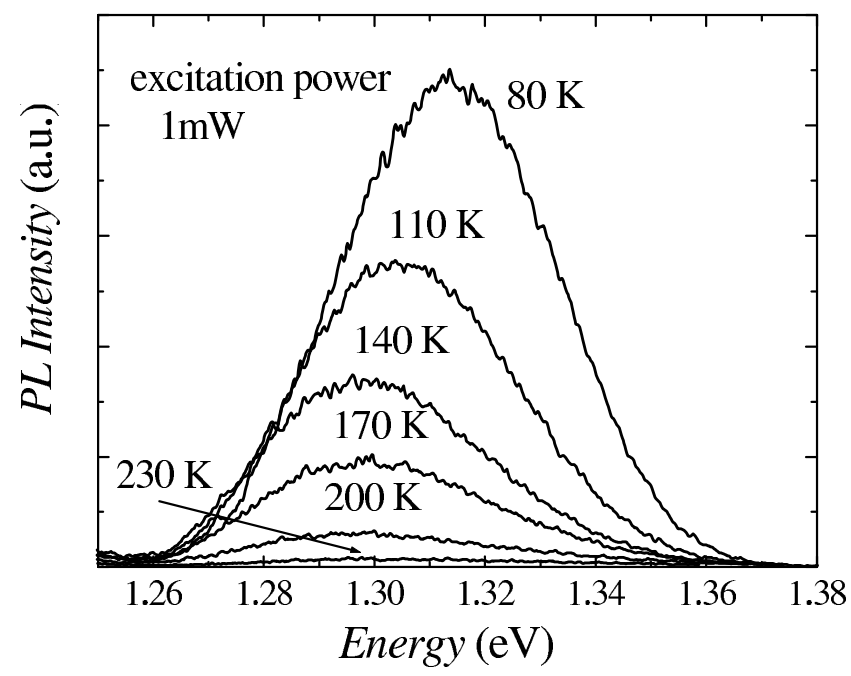

Fig. 2. Temperature evolution of PL spectrum measured under $1 \mathrm{~mW}$ excitation intensity.

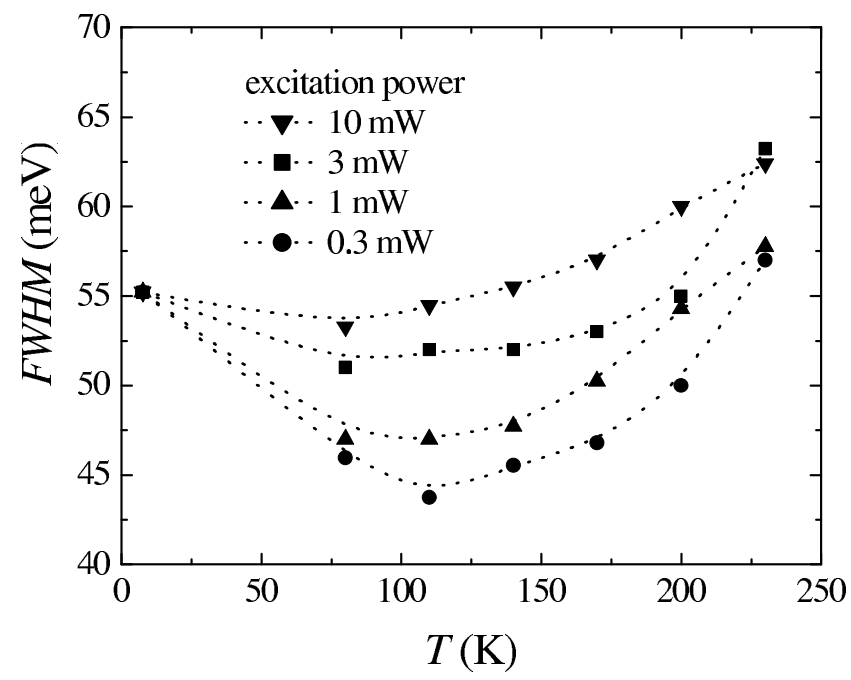

Fig. 3. FWHM of PL spectra obtained after various excitation intensities as a function of temperature.

temperature evolution of the time-integrated PL spectrum recorded by using time-resolved technique after excitation with $1 \mathrm{~mW}$ laser power. As temperature is increased, the luminescence peak shifts to lower energies while the FWHM decreases at intermediate temperatures $(110 \mathrm{~K})$ and only at the highest temperatures starts to increase finally reaching the values found at low temperature. At the same time, photoluminescence quenching with increase of temperature is observed. The FWHM dependence on temperature at different excitation intensities $(0.3-10 \mathrm{~mW})$ is presented in Fig. 3 . As it can be seen, the well pronounced minimum at the intermediate temperatures is obtained only for low excitation power. Figure 4 shows changes in PL spec-

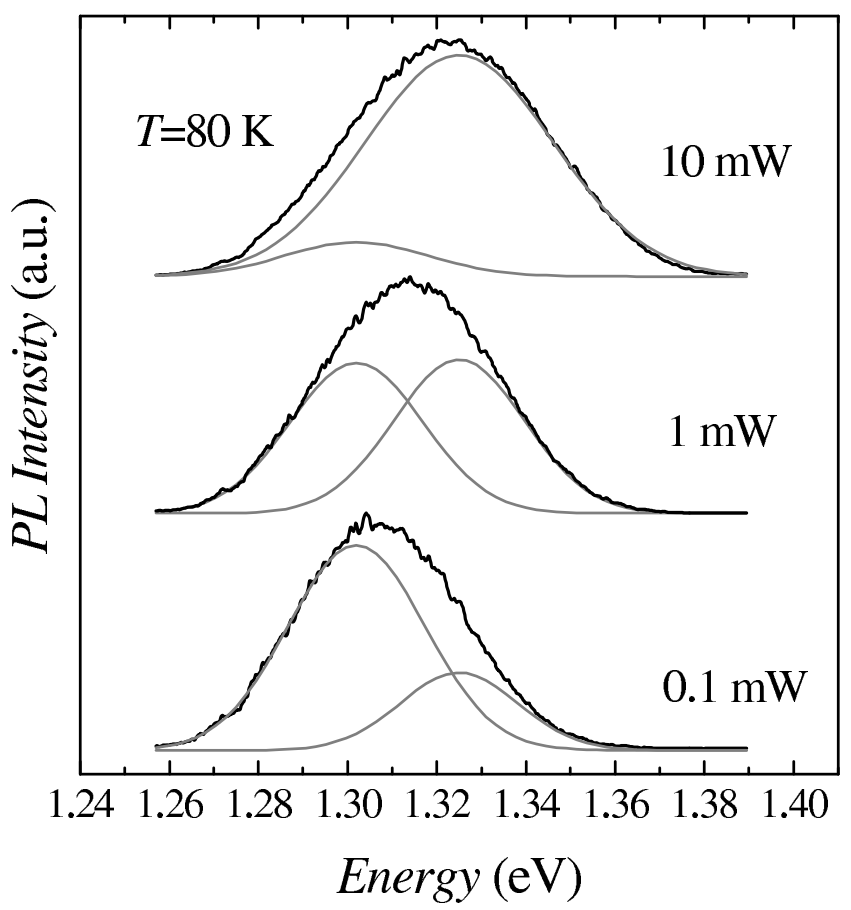

Fig. 4. PL spectra obtained at various excitation intensities and deconvoluted into two Gaussians: one with a maximum at $1.302 \mathrm{eV}$ and the other one at $1.325 \mathrm{eV}$.

tra with increasing excitation power at $80 \mathrm{~K}$. The PL peak with increase of excitation intensities broadens and shifts to higher energies what could be explained as a filling of the higher excited states within the quantum dots and subsequent recombination without relaxation to the ground level. The excited state transitions are not resolved, probably, due to the inhomogeneous broadening and it is impossible to evaluate interlevel distances experimentally. However, simple deconvolution of the PL spectra into two Gaussians (see Fig. 4) with fixed maxima at 1.302 and $1.325 \mathrm{eV}$ yields about $23 \mathrm{meV}$ energy difference between the two peaks. As it can be seen from Fig. 4, the contribution of the excited exciton state increases with the increase of the excitation power. The reported in literature band structure calculations of InAs/GaAs QDs using different approaches yield one or several electron excited states for small QDs [17]. However, the reported results give higher energy difference between ground and excited levels (40-50 meV) [17]. The obtained small energy difference of $23 \mathrm{meV}$ could be explained taking into account very small size of the investigated quantum dots. In such system holes are localized at the apex of the InAs QDs and tightly confined inside the dots, while the electrons are close to the two-dimensional (2D) wetting layer. The electrons are only weakly bound to the dots and spread out into the wetting layer [16]. There- 


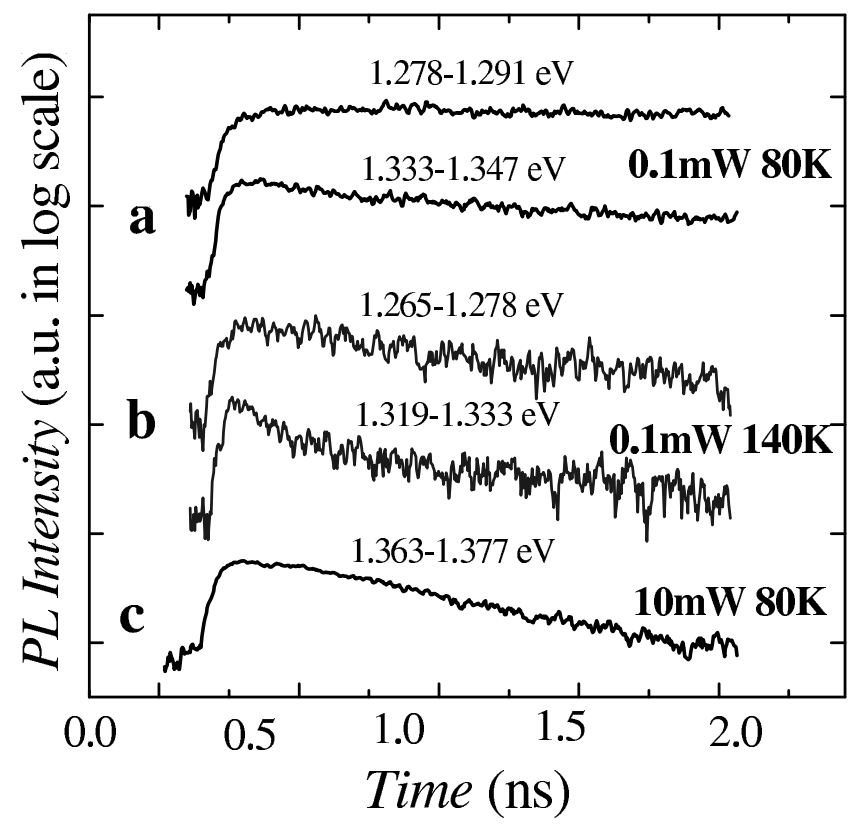

Fig. 5. PL transients at different excitation intensities and temperatures for various energies within the emission band (at low and high energy side) of InAs quantum dots.

fore, in such a case the excited level energy is obtained to be lower in comparison with the results reported in literature, when electrons are confined inside the QDs as well as the holes.

\section{Carrier dynamics in InAs/GaAs quantum dots}

Time-resolved measurements of the investigated quantum dots were performed at different temperatures $(80-230 \mathrm{~K})$ and at different excitation intensities $(0.03-10 \mathrm{~mW})$. It was obtained that the luminescence peak shifts in time to lower energies showing much slower PL decay on the low-energy side than that at the higher one [18].

Typical PL decays for low (a,b) and high (c) excitation intensities at various energies within the emission band are presented in Fig. 5. At low excitation intensity $(0.1 \mathrm{~mW})$ and low temperature $(80 \mathrm{~K})$ decay time is longer than in the case of higher temperature $(140 \mathrm{~K})$ or higher excitation power $(10 \mathrm{~mW})$. The decay times were obtained from the best least-squares fit. Only decay at the lower-energy side of the emission band could be described with one exponential (decay time $\tau$ ), while the high-energy side shows biexponential behaviour $\left(\tau_{1}\right.$ and $\left.\tau_{2}\right)$. The following results are obtained from Fig. 5: (a) $0.1 \mathrm{~mW}$ and $80 \mathrm{~K}: \tau=10 \mathrm{~ns}$ for low-energy side and $\tau_{1}=1 \mathrm{~ns}, \tau_{2}=3 \mathrm{~ns}$ for highenergy side; (b) $0.1 \mathrm{~mW}$ and $140 \mathrm{~K}: \tau=1.7 \mathrm{~ns}$ for low-energy side and $\tau_{1}=0.3 \mathrm{~ns}, \tau_{2}=1.5 \mathrm{~ns}$ for highenergy side; (c) $10 \mathrm{~mW}$ and $80 \mathrm{~K}: \tau=0.38 \mathrm{~ns}$ for highenergy side (excited level). The main features observed in the time-resolved measurements could be summarized as follows. The rise time of the PL is fast for all measured temperatures and excitation intensities and is limited only by the temporal resolution of the measurements $(\leq 50 \mathrm{ps})$. The exclusive feature of this system with very small QDs is very slow decay (1-10 ns) if compared with the results reported in literature $[4,6]$. It could be explained taking into account the separation of electrons and holes in the investigated QDs. With the increased temperature, the photoexcited carrier lifetime becomes faster (Fig. 5(b)). The lifetime after high density excitation (Fig. 5(c)) is also shorter what means faster decay for excited exciton. However, in comparison with decay for systems with larger dots, the lifetime in the excited level is still long enough ( $\sim 400 \mathrm{ps})$. These features are very promising for the development of infrared photodetectors based on QDs with the aim to achieve higher sensitivity of the devices.

The carrier dynamics in small InAs/GaAs quantum dots results from different processes related to trapping and thermal escape of the carriers, their intra- and inter-dot relaxation, and electron-hole recombination. Also, the role of the wetting layer should be taken into account [5]. It should be noted that the PL spectra recorded at different times after the excitation showed the red shift of the peak energies which could be attributed to a relatively high rate of carrier thermal emission out of smaller dots (with higher transition energies) and their subsequent recapture into larger ones. The wetting layer in such a case acts as a transit channel to other QDs or to nonradiative states inside or outside the GaAs barrier. The same behaviour is demonstrated in Fig. 5 showing faster PL decay at the high-energy side of the emission band. The reduction of FWHM of the spectra (see Fig. 3) at low excitation densities at intermediate temperatures $(\sim 110 \mathrm{~K})$ could be an additional argument that carriers are redistributed among the QDs with different sizes.

\section{Optically detected magnetic resonance in small quantum dots}

Due to the exceptionally long exciton lifetimes, up to $10 \mathrm{~ns}$, observed in these structures (see Section 4), it became possible to apply high microwave frequencies ( $95 \mathrm{GHz}$, the W-band) to InAs/GaAs quantum dots in order to perform the ODMR spectroscopy measurements. 


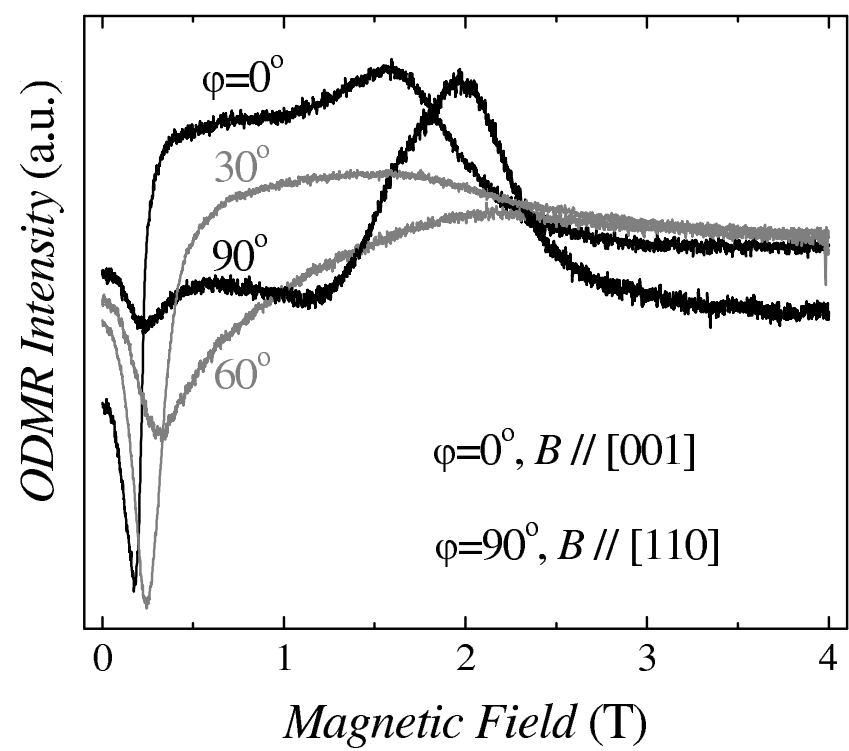

Fig. 6. Dependence of the ODMR spectrum on the angle of the static magnetic field. Rotation is performed from $\mathbf{B} \|[001]$ (B parallel to the growth direction of the structure) towards $\mathbf{B} \|[110]$ ( $\mathbf{B}$ in plane of the dots).

Figure 6 presents the dependence of optically detected microwave resonance spectra on the angle of the static magnetic field $\mathbf{B}$. In the case when $\mathbf{B}$ is parallel to the growth axis $z$ of the sample $\left(0^{\circ}\right)$, two spectral features with opposite sign of PL change are observed: one at $B=0.18 \mathrm{~T}$ (width $0.13 \mathrm{~T}$ ) corresponding to a microwave-induced decrease in intensity, and a broader one at $B=1.6 \mathrm{~T}$ (width $0.6 \mathrm{~T}$ ) showing the opposite phase. A strong anisotropy of the signals is observed. Upon rotation of the sample or the static magnetic field direction away from the $\mathbf{B} \|[001]$ position, the low-field line broadens while moving towards higher fields. After rotation greater than $30^{\circ}$ from the parallel direction, the peak maximum is shifted to $0.25 \mathrm{~T}$ and is broadened to a width of $0.2 \mathrm{~T}$, showing confinement effects. The high-field line, however, is observed only close to the parallel direction, and vanishes upon rotation of less than $25^{\circ}$. The ODMR experiments performed with a sample grown under the same conditions but without the formation of QDs (only an InAs monolayer) did not show any resonance in the microwave-induced changes of the PL intensity. This demonstrates that the observed ODMR signals are directly related to the electronic states of the InAs QDs. The obtained low-field signal is ascribed to cyclotron resonance of the electron in 2D $\mathrm{WL}$, corresponding to an effective electron mass of $0.053 m_{0}$. This value lies between the electron effective mass in bulk InAs and that in GaAs. Enhance-

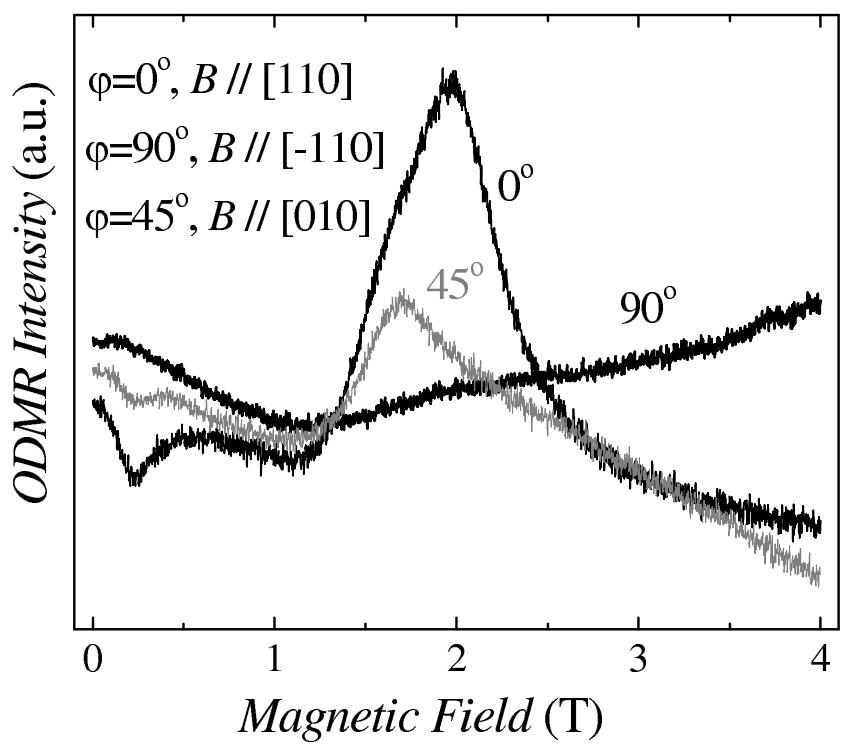

Fig. 7. Dependence of the ODMR spectrum on the angle of the static magnetic field when rotating it in the plane of the dots: from $\mathbf{B} \|[110]$ towards $\mathbf{B} \|[-110]$.

ment of the electron mass has been reported for QWs and superlattices due to confinement effects, therefore, the obtained result is in good agreement with the literature: a value of $0.050 m_{0}$ was found for InAs/GaSb QW [19]. The microwave-induced signals at higher magnetic fields were attributed to magnetic resonance transitions between spin states of the holes confined in the dots and the effective $g_{h}$-factors were obtained as follows: $g_{h}=4.2$ for $\mathbf{B} \|[001]$ and 3.3 for $\mathbf{B} \|[110]$ direction.

The ODMR spectra obtained upon the rotation of the static magnetic field in the QDs plane (see Fig. 7) were different in different crystallographic directions. The InAs quantum dots are expected to have a pyramidal shape for which the $[110]$ and the $[-110]$ directions are equivalent. The change of the ODMR spectrum with rotation of the static magnetic field in the QDs plane could be explained by the complicated nonsymmetric shape of the dots in plane or by strain which influences the electronic structure of the dots and spin flip properties of the holes and electrons in different crystallographic directions. As already discussed in Section 4 , the relatively long exciton radiative lifetimes could be explained taking into account that the electrons in the quantum dots are spread out into the wetting layer and, therefore, are separated from the holes in the dots. The observed ODMR peaks in the [110] direction, vanishing upon the rotation of magnetic field towards the $[-110]$ direction, could be an indication 
that electron confinement in the QDs plane is very anisotropic.

\section{Conclusions}

The photoluminescence properties of small InAs/GaAs quantum dots have been studied by using $\mathrm{cw}$, time-resolved and microwave resonance techniques. Time-resolved measurements of carrier dynamics showed that photoexcited carrier capture into the QDs after nonresonant excitation is very fast and no PL was observed from the InAs wetting layer. Very long exciton lifetimes, up to $10 \mathrm{~ns}$, were observed for these small QDs with shallowly confined electrons. This feature could be promising in developing high-performance QD-based infrared photodetectors. PL quenching in InAs/GaAs QDs, obtained with increase of temperature, is supposed to be determined by thermal escape of carriers from QDs and their transfer via the wetting layer to nonradiative states. PL decay at the high-energy side of the spectrum is found to be much faster than that at the lowenergy side which is probably related to carrier redistribution among QDs of different size using the wetting layer as a transit channel. The shift of the PL spectrum to higher energies at higher excitation intensities, broadening, and faster decay are ascribed to population of higher excited states by carriers in the QDs.

The microwave resonance measurements of quantum dots allow one to evaluate the effective mass of the carriers and to get information on the electron confinement and spin splitting of the electron and hole energy levels in the presence of magnetic field, what is important for the development of optoelectronic devices.

\section{Acknowledgements}

The author sincerely thanks J.H. Wolter and P.M. Koenraad (Eindhoven University of Technology) for providing the InAs/GaAs QD samples, E. Goovaerts and G. Janssen (University of Antwerp) for collaboration, assistance, and valuable discussions, and S. Marcinkevičius (Royal Institute of Technology, Stockholm) for performing the time-resolved measurements of the InAs quantum dots.

\section{References}

[1] H.C. Liu, Opto-Electronics Rev. 11(1), 1-5 (2003).

[2] L. Chu, A. Zrenner, M. Bichler, and G. Abstreiter, Appl. Phys. Lett. 79(14), 2249-2251 (2001).

[3] P. Bhattacharya, S. Krishna, J. Phillips, P.J. McCann, and K. Namjou, J. Cryst. Growth 227-228, 27-35 (2001).

[4] R. Heitz, M. Veit, N.N. Ledentsov, A. Hoffmann, D. Bimberg, V.M. Ustinov, P.S. Kop'ev, and Zh.I. Alferov, Phys. Rev. B 56(16), 10435-10445 (1997).

[5] S. Sanguinetti, M. Henini, M. Grassi Alessi, M. Capizzi, P. Frigeri, and S. Franchi, Phys. Rev. B 60(11), 8276-8283 (1999).

[6] Yu.I. Mazur, J.W. Tomm, V. Petrov, G.G. Tarasov, H. Kissel, C. Walther, Z.Ya. Zhuchenko, and W.T. Masselink, Appl. Phys. Lett. 78(21), 3214-3216 (2001).

[7] R. Heitz, H. Born, F. Guffarth, O. Stier, A. Schliwa, A. Hoffmann, and D. Bimberg, Phys. Rev. B 64, 241305-1-241305-4 (R) (2001).

[8] X. Li and Y. Arakawa, Phys. Rev. B 56(16), 1042310427 (1997).

[9] A.L. Efros, V.A. Kharchenko, and M. Rosen, Solid State Commun. 93(4), 281-284 (1995).

[10] M. Sugawara, Phys. Rev. B 51(16), 10743-10754 (1995).

[11] B. Cavenett, Adv. Phys. 30(4), 475-538 (1981).

[12] H.W. van Kesteren, E.C. Cosman, W.A.J.A. van der Poel, and C.T. Foxon, Phys. Rev. B 41, 5283-5292 (1990).

[13] N. Žurauskienè, G. Janssen, E. Goovaerts, A. Bouwen, D. Schoemaker, P.M. Koenraad, and J.H. Wolter, Phys. Status Solidi B 224, 551-554 (2001).

[14] G. Janssen, N. Žurauskienè, B. Partoens, B. Van Daele, E. Goovaerts, A. Bouwen, P.M. Koenraad, and J.H. Wolter, Phys. Rev. B 68, 045329-1-045329-6 (2003).

[15] G. Janssen, A microwave resonance investigation of quantum confined structures and defects in crystalline semiconductors, Ph.D. Thesis (University of Antwerp, 2004).

[16] A.W.E. Minnaert, A.Yu. Silov, W. van der Vleuten, J.E.M. Haverkort, and J.H. Wolter, Phys. Rev. B 63, 075303-1-075303-4 (2001).

[17] O. Stier, M. Grundmann, and D. Bimberg, Phys. Rev. B 59(8), 5688-5701 (1999).

[18] N. Žurauskienė, S. Marcinkevičius, G. Janssen, E. Goovaerts, A. Bouwen, P.M. Koenraad, and J.H. Wolter, Materials Sci. Forum 384-385, 31-34 (2002).

[19] T.P. Smith III and F.F. Fang, Phys. Rev. B 35, 77297731 (1987). 


\title{
MAŽŲ PUSLAIDININKINIŲ KVANTINIŲ TAŠKŲ FOTOLIUMINESCENCIJA
}

\author{
N. Žurauskienè
}

Puslaidininkiu fizikos institutas, Vilnius, Lietuva

\begin{abstract}
Santrauka
Pateikti rezultatai, gauti tiriant ypač mažų $(\sim 7 \mathrm{~nm}) \mathrm{InAs} / \mathrm{GaAs}$ kvantinių tašku (KT), užaugintų molekulinių pluoštelių epitaksijos būdu, fotoliuminescenciją. Nerezonansiškai fotosužadintu krūvininkų dinamika buvo tiriama nuo 80 iki $230 \mathrm{~K}$ temperatūros ruože, naudojant 80 fs trukmès Ti:safyro lazeri $(800 \mathrm{~nm})$. Rasta, jog laike išskirtai InAs kvantinių taškų fotoliuminescencijai būdinga trumpa ( $\sim 50 \mathrm{ps})$ užaugimo trukmè, o eksitonu gyvavimo trukmé yra pakankamai ilga ir žemoje temperatūroje $(80 \mathrm{~K})$ siekia $10 \mathrm{~ns}$. Temperatūrai kylant, buvo pastebetas fotoliuminescencijos gesimas, kuri galima paaiškinti krūvininkų terminiu išlaisvinimu iš KT ir jų nespinduline rekombinacija. Taip pat pastebeta, kad fotoliu-
\end{abstract}

minescencijos gesimas didesnių KT spektro juostos energijos verčiu srityje yra daug spartesnis, lyginant ji su mažų energijos verčių sritimi. Galima paaiškinti, kad tai vyksta dèl krūvininkų terminio išlaisvinimo iš mažų kvantinių taškų ir perèjimo per drèkinamaji kvantinio darinio sluoksni i didesnių matmenu (mažesnès spinduliavimo energijos) kvantinius taškus. Eksitonų smulkioji sandara buvo tirta, naudojant optiškai detektuojamo magnetinio rezonanso metodą, matuojant bendrą fotoliuminescencijos intensyvumo pokyti, paveikus kvantinius taškus $95 \mathrm{GHz}$ mikrobangomis ir keičiant išorini pastovų magnetini lauką nuo 0 iki $6 \mathrm{~T}$. Gautieji rezultatai aptarti, parodant mažų kvantinių taškų perspektyvumą, kuriant infraraudonosios šviesos jutiklius. 